\title{
The advances in the foliar application of micro and macronutrients and their effects on growth development and yield potential of tomato crops
}

\author{
*Wassem Ahmed \\ Department of Horticulture, The University of Haripur, Pakistan \\ *Corresponding Author" s Email: waseemuaf12@gmail.com
}

\begin{abstract}
Tomatoes, also referred to as poor man orange, are a great source of antioxidants; Vitamin $\mathrm{K}$ and $\mathrm{C}$, which are beneficial to the health of the human being, play a significant role in processes industries. This review article aims to highlight the uptake of mineral nutrients from foliar fertilization of tomato for its growth and developmental responses of various cells and tissue. It holds several health assistances, including urinary tract infection, skin problems, diabetes, hypertension, and various cancers. Despite several kinds of research conducted on many characteristics of foliar fertilization while many are still unknown. In tomato, foliar fertilization is the most effective method compared to soil nutrient availability, which is low, topsoil dry, and root activity during the reproductive stage is decreased. Foliar fertilization is also successful in increasing the content of the fruit, yield, and the potential for the developmental process. It is anticipated that the foliar fertilizer should be recommended in the integrated tomato production. It provides a link between the treatment of micro and macronutrients and helpful in boosting productivity leading to quality of tomato crop and environment friendly. This review article discusses the effect of various nutrients, methods, and applications on the quality and quantity of tomatoes. In addition, their effects on the vegetative and reproductive stages of tomatoes are also discussed.
\end{abstract}

Keywords: Tomato, foliar application, quality, and quantity

Highlights

$>$ Tomato is very effective for the health of human being

$>$ Tomato is a rich resource of antioxidant, Vitamin $\mathrm{C}$ and $\mathrm{K}$

$>$ Foliar application of micro and macronutrient results in healthy growth of the tomato plants

\section{Introduction}

Tomato (Lycopersicon esculentum Mill) may be an outstanding member of the Solanaceae family with $2 \mathrm{n}=24$ chromosomes, originated within the premises of the Western coastal plains of South America (Ali et al., 2012). Tomato is one of the supreme fruit vegetable grown up around the globe, and in terms of the world, as a processing crop, it ranks 1st within the world whereas ranks next to potato. It grows within the warm season annually with the typical optimum growing temperature ranging from $25^{\circ} \mathrm{C}$ to $29^{\circ} \mathrm{C}$ (Ejaz et al., 2011). Generally, its two are cultivated throughout the spring and fall seasons in the Asian country. Tomato has gained immense significance within the country as a fruit vegetable. It is cultivated on thousands of hectares of about 52.3 with a complete annual production of around 529.6 thousand tonnes. (Naz et al., 2011). Besides these nutrients, it additionally includes $\beta$-carotene and lycopene pigments. Lycopene is exceptionally very important because it is responsible for the several red color characteristics of tomatoes. Tomatoes additionally keep the blood vessels in healthy condition and stop scurvy (Ejaz et al., 2011).

\subsection{Role of fertilization and nutrients as an essential part of growth}

Crop fertilization is what the most typical culture follows, and farmers use it to maximize the yield of vegetables like tomato crops. It's currently turning into obligatory with intensive land use and agricultural advancement to fertilize farmlands beneath crop cultivation to realize satisfactory yield in tomatoes (Williams and Harris, 1986). Two types of fertilizers are available for crops, e.g., organic (manure) and inorganic (synthetic). Organic manures will improve soil-water-plant relations by modifying the total body, bulk density, and increasing water use potency, plant growth, and yield (Oikeh and Asiegbu, 1993; Yafan and Barker, 2004). In contrast, inorganic fertilizers are expensive and crucial for plants' growth and are applied to soil feeding where a large quantity is needed compared to foliar application. The standard of tomato fruits is diversely affected once grown up beneath deficient nutrients conditions, as balanced crop nutrition is considered a requirement for proper plant growth, high yield, and premium quality. Typical or foliar application ways could also be used for nutrients enhancement in the crops as they work promptly for crop plant development. (Naz et al., 2012). Therefore, this 
peculiar foliar feeding property makes this mode of nutrient application higher than soil feeding. For good tomato production, it is essential to use a foliar application of macro and micronutrients. (Kuepper, 2003).

All vegetables respond positively to applying small macro-nutrients (Mallick and Mathukrishnan, 1980; Naz et al., 2012). Moreover, the current international situation powerfully emphasizes the requirement to adopt agricultural property practices for adequate food production. The inorganic fertilizers square measure pricey, and these square measures typically out of the reach of small marginal farmers. So, farmers typically cannot afford to use artificial macronutrients in giant or adequate quantities (Mehdizadeh et al., 2013). Hence, an alternate is to use a small quantity of those fertilizers within the kind of foliar application. The critical functions of micronutrients area unit assist the natural action and conjointly the synthesis of chlorophyll in inexperienced plants. The nitrogen, boron, copper, and zinc area unit is classified as essential macro and micro-nutrients, and these area units are required for proper plant growth, development, and yield.

Moreover, a tomato's quality and yield potential can be enhanced by preserving an adequate nutrient level by soil or foliar application. Generally, both macro and micronutrients play an imperative role in quality tomato production. Tomato crop demands heavy and sufficient quantity of fertilizers for high yield Mehdizadeh et al., 2013). For improving tomato plant growth and development, both organic as well as inorganic manures are essential. It is now a well-established point that chemical fertilizers increase the growth of plants directly. Therefore, based on the above facts, supplementary dosages of $\mathrm{N}, \mathrm{B}$, and $\mathrm{Zn}$ with different combinations and concentrations were used as foliar feeding to investigate their possible effects on growth, flowering, and yield of tomato crop (Mehdizadeh et al., 2013).

\subsection{Significant nutrient changes in tomato under several macro nutrient's application}

\subsubsection{Effect of Nitrogen application on the tomato for the vegetative growth process}

The imperative nutrient nitrogen $(\mathrm{N})$ is supplied to plants in both anionic $\left(\mathrm{NO}_{3}{ }^{-}\right)$and cationic $\left(\mathrm{NH}_{4}^{+}\right)$forms $($Forde and Clarkson, 1999); therefore, the part of $\mathrm{NH}_{4}{ }^{+}$to the whole $\mathrm{N}$ supply may significantly stimulus the total absorption of cation to anion (Imas et al. 1997; Savvas et al., 2006). However, variations in this ratio are electrochemically compensated for by proportionate adjustments in the invasion or affluence of protons $\left(\mathrm{H}^{+}\right)$or basic anions in the root zone. Thus significantly influencing the rhizosphere $\mathrm{pH}$ (Imas et al., 1997; Lea-Cox et al., 1996). The uptake of $\mathrm{P}$ and other micronutrients affected by the $\mathrm{pH}$ of the external medium, thus persuading thoughtful nutritional disorders (Gerendás et al., 1997; Islam et al., 1980; Marschner, 1995). It is essential to refer that distinct forms of $\mathrm{N}$ impact plant metabolism because of alterations in the assimilation of the intracellular metabolism (Raab \& Terry, 1994).

Earlier research revealed the properties of the sources of $\mathrm{N}$ and its interactions on tomato plants associated with nutritional and ecological issues. Those designated that tomato is vulnerable to the supply of ammonium as a sole or dominating nitrogen form (Errebhi and Wilcox., 1990), while more recent studies have confirmed this consideration. Ammonium is the sole or dominating $\mathrm{N}$ source in a solution culture to tomato plants caused in impaired growth and yield restrictions (Claussen (2002). Researchers reported that when $\mathrm{NH}_{4}-\mathrm{N} /$ total-N in the nutrient solution was higher than 0.1, a constraint in the vegetative development and the fruit yield of tomato in foliar form results (Siddiqi et al., 92002) and Akl et al. 2003). While if the ammonium fraction was 0.25, an increase in fresh and dry weight of fruit was observed (Claussen (2002) and Dong et al., 2004). It was reported by Akl et al. (2003) that if ammonium part in the range 0.15- 0.25 of the total-N supply, results in a reduction of tomato. For the home vegetable grower, the taste is probably the most crucial concern. Commercial growers have many other concerns involved with successfully producing and marketing their crop, in addition to taste.

\subsection{Application of Macronutrient on Quality changes in tomato}

Several studies have directly or indirectly examined the effect of plant nutrition on tomatoes, which are briefly reviewed here as the nutritional quality of the tomato accomplishes by applying nutrients (Kimball and Mitchell, 1981; Davies and Winsor, 1967). The quality of tomato stimulated under the application of potassium superoxide by its buffering capacity via free acid content oxygen and Phosphorus superoxide. Woldemariam et al. 2018 recommended that for the improvement in the yield and quality of tomatoes, balanced N.P.K. and K fertilizers should be used. Their nutrition treatment was found to significantly affect tomato quality, color, and acceptability for marketing (Kimball and Mitchell, 1981) as Tomatoes receiving standard nutrition (100\%) were compared with enhanced nutrition (150\%). Other studies have also shown that $\mathrm{K}$ and P foliar nutrition positively affected fruit sugar and acid content (Lacatus et al., 1994); the nutrition factors, the soil K 
content, showed maximum effects on the total acid content in the fruit. Davies and Winsor (1967) found a positive logarithmic correlation between the $\mathrm{K}$ level in the soil and the acid content of the fruit. However, Wright and Harris (1985) reported that increased nitrogen $\mathrm{N}$ and $\mathrm{K}$ fertilization had a detrimental effect on tomato flavor, even though augmented acidity and solid soluble content caused by collective fertilization.

The productivity of vegetable crops also depends on potassium $(\mathrm{K})$, an essential nutrient linked with the quality features and plays a role in turgor preservation, photosynthesis, and other metabolic processes (Bidari and Hebsur, 2011; Marshner, 1995). Moreover, it is also expanded in the enrichment of lycopene contents of tomato fruit through the synthesis of pigments or carotenoids. It was reported that an increase in $\mathrm{K}$ content in fertilization increase fruit yield and solid contents of the tomato crop (Lachover, 1972). The frequency of both internal and external spotty maturation usually decreased with increased K supply. Hartz et al. (2001) conducted a field survey looking at yield and color under various K fertilizer practices for processing tomatoes. It is suggested that existing soil $\mathrm{K}$ recommendations be adjusted upwards for maximum fruit yield. Optimizing fruit color uniformity may require a more excellent soil $\mathrm{K}$ supply than needed for maximum fruit yield.

$\mathrm{K}$ is found in the ionic form inside the plant only; it is a co-factor of many enzymes. Under $\mathrm{K}$ deficient conditions, the fruit was small in size, lack in red color at an early stage. The red color of fruit and ripening disorders is closely related to fruit's K content (Perkins-Veazie and Robert, 2003). The process of the foliar spray is effective for nutrients application that delivers thorough and gainful agronomy of tomato crop (Oded and Uzi, 2003). Crop plant growers rapidly utilize foliar nutrition; it improves the fruit color (Kowalska, 2003; Oded and Uzi, 2003, Bidari and Hebsur, 2011). The amount of vitamin $\mathrm{C}$ in tomato also depends upon K nutrition (Perkins-Veazie and Robert, 2003). In a ripened fruit, the redder parts contain more K, acids, and sugars (Adams and Ho, 1995).

1.4 Foliar application of some micronutrients on yield and quality of tomatoFoliar spray of micronutrients plays a vital role in conditions where the soil cannot produce the desired nutrients for the development of the plants. This part of the review will highlight those researches that designate that micronutrients contribute to fruit weight, color, dry matter content, and final yield of tomatoes (Anac et al., 1994).

\subsection{Impact of Zinc and boron Zn application on tomato crops}

Cheristensen (2005) reported that foliar spray technology linked with the nutrient addition directly from the pores of the cuticles of the leaf to the epidermal cell wall and actively transfer through the plasma membrane. These micronutrients, through foliar application effectively involved in plant metabolic activities; consequently, the rate of photosynthesis increases, followed by good vegetative and fruit yield observed(Adams, 2002; Mallick and Muthukrishnan, 1980). Zn and $\mathrm{B}$ are central for plant nourishment among other micronutrients, while tomato needs equally macro and micronutrients to its growth (Sainju et al., 2003). Zn is essential for the growth and development of the plant, followed by synthesis of carbohydrates, protein metabolism, and sexual fertilization of plant (Vasconcelos et al., 2011), while deficiency of B reduced yield and quality in tomatoes (Davis et al., 2003). Boron is a necessary micronutrient for the usual progress of higher plants but toxic when in excess and has a harmful effect on the growth and development of crop plants. Boron application on tomato results in effective responses, especially glutamate-oxaloacetate and glutamate-pyruvate transaminase enzymes. Those were augmented under B application, followed by an increase in the root and shoot soluble proteins.

Swan et al. (2001) reported that balanced fertilization of macro and micronutrients could increase production. However, the foliar application of micronutrients is associated with an economical and secured manner (Aghtape et al., 2011). Plant height of tomato exaggerated under the $\mathrm{Zn}$ and B nutrients (Hatwar et al., 2003). Singh and Tiwari (2013) additionally determined herbaceous plant height responses by foliar application of various micronutrients. Herbaceous plant height ranged from 122.0 to $137.0 \mathrm{~cm}$ among the various concentrations and nutrients (Davis, 2003). Zn helps on phytohormone synthesis and, in association with B, helps in cell wall development and cell differentiation of plants (Basavarajeswari et al., 2008).

\subsubsection{Iron}

A high $\mathrm{pH}$ level within the root zone of the vascular plant is related to iron deficiency leads to frequent biological process issues. Though, tomato does not seem to be vulnerable to an iron deficiency under conditions of moderately high $\mathrm{pH}$ (6-7) in the root zone (Islam et al., 1980; Akl et al., 2003), whereas iron deficiency in tomato is characterized by a forceful reduction of the leaf chlorophyll content (Dasgan et al., 2003). However, partial use of the chemical element in ammonia might scale back iron deficiency anemia symptoms in tomatoes, particularly in soilless plants (Sonneveld, 2002). Iron foliage spraying is another effective means of avoiding or even curing an iron deficiency (Fernández and Ebert, 2005; He et al., 2005). Fe uptake improves by combining Fe-EDDHA with organic compounds such as commercial humic substances 
or their mixtures of amino acids. Iron uptake also improves by combining Fe-EDDHA with organic compounds like industrial soil substances or their mixtures of amino acids. The characterization of the Fe nutritional status of tomato is related with Fe-containing enzymes, specifically ascorbate peroxidase, catalase, and guaiacol peroxidase, and found more reliable criteria for the characterization of the Fe nutritional status in tomato.(Ruiz et al., 2000; Dasgan et al., 2003). It was documented that foliar spray of $\mathrm{Fe}$ with metallic element, $\mathrm{Zu}, \mathrm{B}, \mathrm{Mn}$ leads to smart growth of the plants with the excellent variety of fruits per plant followed by the burden of single fruits and seeds(Tamilselvi et al. 2002).

Also, numerous additional problems, just like the $\mathrm{pH}$ of the rhizosphere, the genotype, the amount of soluble iron, phosphorus, bicarbonates, organic matter, and wet content within the root zone, might influence the uptake of iron by tomato (Ruiz et al., 2000; Dasgan et al., 2004). Furthermore, heat stress at $\mathrm{T}=35^{\circ} \mathrm{C}$ diminished $\mathrm{Fe}$-chelate enzyme, aconitase, guaiacol oxidase, catalase, and Fe-superoxide dismutase (Dasgan et al., 2002; Rivero et al., 2004). As per Wang et al. (2002) reports, many genes are concerned in iron uptake below Fe-limiting conditions within the root zone, and therefore the expression of those genes is induced inside one hour when withholding iron from the roots of intact plants (Ling et al., 2002; Yuan et al., 2005).

\subsubsection{Manganese}

$\mathrm{Mn}$ is a mobile micronutrient required for the synthesis of chlorophyll. At the same time, the deficiency of the Mn is associated with the soil having higher $\mathrm{pH}$ or alkaline in nature and appeared in plants when the water of irrigation contains bicarbonates at higher concentration followed by pale green leaves and reduced growth rate of the crops. Shenker et al. (2004) investigated the growth of tomatoes under very high low Mn concentration in the root zone. The recommended concentration range found adequate for tomato was 50-500 mg kg-1 in mature leaves (Reuter and Robinson, (1986). However, Shenker et al. (2004) found that the growth and the chlorophyll pigments of the plants with a leaf Mn concentration of $16.8 \mathrm{mg} \mathrm{kg}^{-1}$ were not significantly lower than those of plants with leaf Mn levels falling within the above range of adequacy, while a leaf Mn concentration of $207.4 \mathrm{mg} \mathrm{kg}^{-1}$ was associated with toxicity symptoms. According to Mills and Jones (1996), Mn concentration of $250 \mathrm{mg} \mathrm{kg}-1$ in the leaf petioles is the maximum safe level for tomatoes ( Le Bot et al., 1990). Generally, high Mn is accountable for reducing the Fe uptake due to competition in uptake mediated by common metal transporters (Korshunova et al., 1999). Consequently, in some cases, an increase in the external foliar spray of Mn concentration is recommended to enhance the shoot Fe concentration in tomato (Gunes et al., 1998; Shenker et al., 2004).

\subsection{Role of nutrient on aquaponic and hydroponic production systems of tomato}

Aquaponics is an integrated system of aquaculture and hydroponic cultivation. Water circulates between the components of the system (fish tank, biofilter, hydroponic system), during which the feces of the fish become fertilizers for the plants, and the nitrifying bacteria in the biofilter convert the nitrogen form from ammonia to nitrate, which the plants absorb. Cu is a significant micronutrient, but it decreases cluster number in hydroponics while no effect on fruit number and yield (Graber and Junge, 2009). Aquaponics is the integration of hydroponic plant production into recirculating fish aquaculture systems (Nelson, 2008). In the aquaponic system, nutrients expelled straight away by the fish or produced by the microbial degradation of organic wastes are fascinated by plants cultured hydroponically.

Aquaponics has several advantages over the hydroponic system as they use inorganic nutrient solutions. Fish forage affords the utmost of the nutrients obligatory to plant growth. The majority of fish species utilize 20-30\% of nitrogen (N) supplied by the diet (Hall et al., 1992; Schneider et al., 2005). It indicates that about 70-80\% of the $\mathrm{N}$ supplied by the feed is released as waste into the water (Krom et al., 1995). Usually, recirculating aquaponic systems employ either a media-filled raised bed, nutrient film technique (N.F.T.), or floating raft system (Diver, 2006) for the plant growing area. It is reported that aquaponic systems that rely solely on fish waste to supply nutrients for plants have low levels of phosphorus (P), potassium $(\mathrm{K})$, iron (Fe), manganese (Mn), and sulfur (S) (Graber and Junge, 2009). Thus, optimizing plant production may require fertilizer supplementation in aquaponic systems (Rakocy et al., 1997).

On the other hand, the management of a tomato crop is slightly more intricate than leafy crops because the nutrient demands of the plant altered throughout diverse stages of plant growth. During six weeks of germination of the plants to first flowers, the plant's needs of nutrients are pretty constant. While when fruiting is started in the plants, extra nutrients like $\mathrm{Ca}, \mathrm{Mg}$, and $\mathrm{K}$ are required for good yield (Nelson, 2008). The nutrients can be applied to the growing medium or using foliar spraying, which some researchers recognize as a very efficient method of plant nutrition during the intensive growth stage (Giskin et al., 1984; Komosa., 1990). Foliar applications of Mg, Zn, and Mn can effectively alleviate deficiencies in fruit and vegetable crops grown on calcareous soils with a pH of 7.4-8.4 (Jifon, Lester, 2009).

\subsection{The difference in aquaponic and hydroponic systems and cluster numbers}


The hydroponics and aquaponics treatments system experienced on tomato plants reveals substantial alteration $(\mathrm{P}<0.05)$ in biomass improvement. At the same time, no visual difference was observed in the morphology of both systems, with no significant difference in nutrient deficiencies. Moreover, the cluster number per plant in aquaponics was lower than in hydroponics treatments which was increased with foliar application of $\mathrm{K}$ and Fe elements

\subsection{Effect of foliar application of macro and micronutrients on vegetative growth of tomato}

Foliar application of $\mathrm{K}, \mathrm{Mg}, \mathrm{Fe}, \mathrm{Mn}$, and B increased vegetative growth of plants in the aquaponics. Fish do not need K. It is not added to fish feed; thus, the system contained $\mathrm{K}$ in inadequate amounts (Graber and Junge, 2009; Tisdale et al., 1985). The higher effect of foliar application of these elements in the aquaponics may be due to lower nutrient concentrations in nutrient solutions. Thus, foliar spray of $\mathrm{K}$ increased the tomato growth in aquaponics significantly due to the low level of $\mathrm{K}$ in it. Kaya et al. (2001) reported foliar application of supplementary K increased dry matter of tomato plants in salinity stress conditions. However, it should be noted that nutrients are removed without replacement for one week in hydroponic systems. At the same time, they are produced in aquaponics by the fish excretion or by the microbial breakdown of organic wastes continuously (Nelson, 2008).

\subsection{Foliar application of Chitosin arbuscular mycorrhizal fungi}

With the advancement of the world, foliar spray and root treatment are undertaken to improve the soil quality and increase the micro and macronutrient of the crops using biofertilizers and beneficial microorganisms. El Amerany et al. (2020) applied Ch-derived nanoparticles (N.P.s) on tomato plants colonized with the A.M.F. Rhizophagus irregularis (Fig 1), where they observe an increase in biomass of the shoot of the tomato plants and the number of flowers. However, no effect of chitosan spray-on sugar and Phyto Harmon level was observed. At the same time, reduced interaction with A.M.F. was also reported through root treatment which did not affect these parameters. Several studies showed that ch nanostructured (ch N.P.s) has a positive effect on the growth and cell of the plants due its nano-size (Benhamou \& Thériault 1992), The promoting effect of Ch N.P.s on plants related to its small size, active functional group, large surface area, higher encapsulation efficiency, and its cationic nature (Mohammed et al. 2017). It was also observed that ch N.P.s effectively controlled the pathogenic effects, primarily on tomato plants (Solanum lycopersicum L.), against fungal attack (Sathiyabama et al.,2014). It is also established that effects are linked with its assumed physical properties, covering the root area, thus blocking the fungal interaction (Gryndler et al. 2003). Moreover, Ch also enhanced the expression of genes due to the programming of hydrolytic enzymes, such as like $\beta$-1,3-glucanase and chitinases. Agbodjato et al. (2016) reported the positive effect of $\mathrm{Ch}$, which might keep the capability and promote the activity of some beneficial microorganisms, such as plant growth-promoting rhizobacteria (PGPR) and arbuscular mycorrhizal fungi (A.M.F.). Regarding the A.M.F. fungi, several studies reflect that the dual symbiosis between plants and A.M.F. encouraged the growth of the plants and indorsed the root development by intensifying nutrient accumulation (Azmat et al., 2015). Healthy growth of the plants was observed under AM inoculation by increasing the tolerance to biotic and abiotic stresses or even by inducing disease resistance (Liao et al., 2018). Sultana et al. (2017) reported the plant height and number of the flowers in tomato and eggplants under an oligo chitosan dose of 60 and 100ppm. The yield of tomato under two doses (41.67 and $38.30 \mathrm{~kg}$, respectively) was higher than the yield of control plants $(22.79 \mathrm{~kg})$. In another investigation, chitosan was applied to manage the drought stress victimization of the tomato plants with many chitosan concentrations like $(0,50,100,150 \mathrm{mg}$ L-1) couple with water stress intervals $(3,6,9$, and twelve days) got. The study showed that varied chitosan and water stress interval applications had a big $(\mathrm{P}<0.01)$ result on most studied parameters. Tomato plants treated with half-dozen days water stress interval had most average plant height $(82.69 \mathrm{~cm})$, average vary of leaves $(104.02)$, leaf space $(81.47 \mathrm{~cm} 2)$, pigment content $(71.31 \mathrm{SPAD})$, relative water content $(67.27 \%)$, excised leaf water retention $(68.24 \%)$, vary of fruit plant-1(24.66), average fruit weight (73.718 g) and yield (37.50-ton ha-1). Similarly, foliar application of chitosan at $100 \mathrm{mg} \mathrm{L}-1$ resulted from most average plant height $(80.74 \mathrm{~cm})$, every day varies of leaves $(104.19)$, leaf space $(81.05 \mathrm{~cm} 2)$, pigment content $(72.29$ SPAD), relative water content (66.82\%), excised leaf water retention (66.58\%), fruit plant-1 (24.33), average fruit weight (74.74 g) and yield (37.37 ton ha-1). it's over that $100 \mathrm{mg} \mathrm{L-1chitosan}$ application at the aspect of a half-dozen days water interval had a positive impact on the growth and quality of tomatoes (Hassnain et al. 2020). 

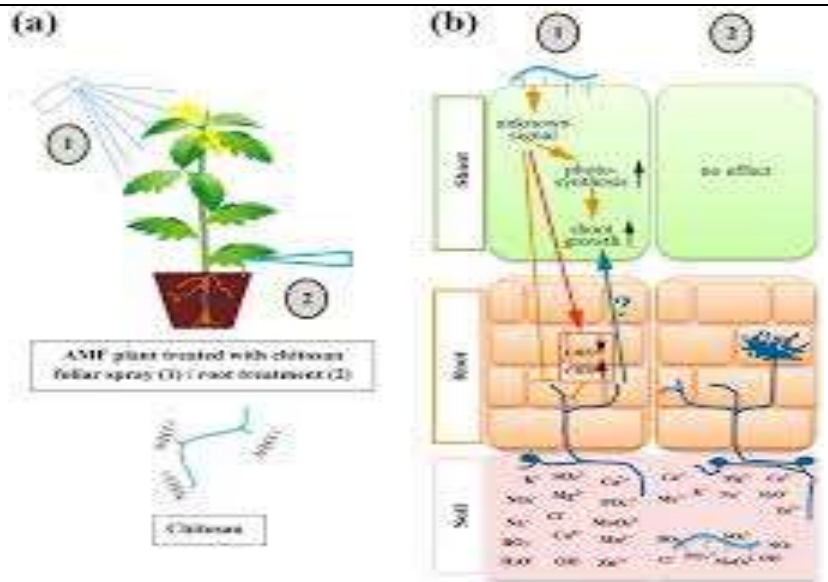

Fig 1 Foiliar application of chitosan on tomato plant (El Amerany et al 2020)

\subsection{Role of fruit firmness and quality of tomato}

The production of quality tomatoes is illustrated to fruit firmness that allowed them to ripen more fully on the vine, therefore apprising superior taste and higher customer demand. Moreover, something that stimulates plasma membrane structure and strength affects the fruit firmness of tomatoes. The metallic element is employed by the plant to manufacture new plasma membranes and is vital in maintaining the correct cell wall structure. Awar and Karami also report (2016) that foliar chemical treatments on the flesh firmness of tomato at treatments of metallic element had the very best rate of firmness $\left(6.36 \mathrm{~g} / \mathrm{cm}^{2}\right)$; the firmness for Iron Chelate and Sulfates were vi.13 and $5.66 \mathrm{~g} / \mathrm{cm}^{2}$ (Malakouti and Rezaie, 2001).

Its requirement by plants is an essential nutrient obligatory in all stages of the growth, while its proper supply may be disturbed due to the excessive magnesium in the roots zone. Therefore, the appropriate calcium: magnesium ratio is desirable for proper calcium nutrition. Generally, plants required a 2:1 $\mathrm{Ca}$ and $\mathrm{Mg}$ ions ratio for proper firmness of the fruits. Also, ripe green tomatoes were put in a solution of calcium chloride and calcium nitrate. Compared to the control treatment, it was observed that tomato-tonality is delayed, and firmness and storage time increase (Rezaie, 2014). In another study by Shornikova et al. (1971), they suggested that calcium chloride positively affects the maintenance of tomatoes. It increases the resistance of tomatoes during storage time and transportation process because of the impact of micronutrients on the flesh firmness of tomatoes.

Additionally, tomato is more likely to be tainted after the harvest time. The percentage of waste increases due to its soft texture, wateriness, the distance between the production site and consumption place if transport condition is not appropriate. The higher the firmness is, the less the ratio of fruit water to the flesh will be, and as a result, the fruit will be more resistant to the damages caused by transportation (Rezaie, 2014). Any observed sign of contamination, decay, and softening in the fruit makes it a less friendly-market product (Esna-Ashar et al., 2008). In an experiment, tomatoes fed by Iron fertilizer were more long-lasting in firmness and more friendly-market product.

\section{Conclusion}

Based on previous studies, the foliar application to tomato plants significantly affects the plant's growth and developmental process. Foliar fertilization should be applied under conditions of decreased nutrient availability in soil, dry topsoil, and decreased root activity during the reproductive stage. However, the efficiency of foliar fertilization depends on nutrient mobility within a plant with their interaction roles. Nutrients which belong to phloem-mobile faced efficiency of this measurement is prevalent. However, the use of these products frequently leads to several problems, e.g., (1) low absorption rates, especially in the leaves with thick cuticles; (2) run-off from the hydrophobic surface; (3) rapid drying of the spray solution and (4) leaf damage. Despite many accomplished studies on foliar application of mineral nutrients, many aspects of the uptake and nutrient translocation within a plant are unfamiliar. Therefore, further research in this area is needed to highlight this aspect.

\section{Acknowledgment}


The author is thankful to the Dean Faculty of Science, the University of Haripur, for providing funds for tomatoes crop investigation

\section{Conflict of interest}

It is declared that there is no conflict of interest among the authors.

\section{References}

Ali W, Jilani MS, Naeem N, Waseem K, Khan J, Ahmad MJ, Ghazanfarullah. (2012). Evaluation of different hybrids of tomato under the climatic conditions of Peshawar. Sarhad Journal of Agriculture 28(2), 207-212.

Ejaz, M., Rehman, S. U., Waqas, R., Manan, A., Imran, M., \& Bukhari, M. A. (2011). Combined efficacy of macro-nutrients and micro-nutrients as a foliar application on growth and yield of tomato grown by vegetable forcing. Int J Agro Vet Med Sci, 5(3), 327-335.

Naz F, Haq IU, Asghar S, Shah AS, Rahman A, (2011). Studies on growth, yield and nutritional composition of different tomato cultivars in Battal Valley of District Mansehra, Khyber Pakhtunkhwa, Pakistan. Sarhad Journal of Agriculture 27(4), $569-571$.

Williams LB, Harris G. (1986). Fertilizer marketing in Nigeria. Fertilizer International 225, 45-49. 20

Oikeh SO, Asiegbu JE. (1993). Growth and yield responses of tomatoes to sources and rates of organic manures in ferralitic soils. Bioresource Technology, 45(1), 21-25. http://dx.doi.org/10.1016/0960-8524(93)90138-2. 18

Yafan H, Barker AV. (2004). Effect of composts and their combinations with other materials and their combinations with other materials on nutrient accumulation in tomato leaves. Communications in Soil Science and Plant Analysis 35(19-20), $2809-2823$.

Naz RMM, Muhammad S, Hamid A, Bibi F. (2012). Effect of boron on the flowering and fruiting of tomato. Sarhad Journal of Agriculture 28(1), 37-40.

Kuepper G. (2003). Foliar Fertilization. ATTRA (Appropriate Technology Transfer for Rural Areas). Available online at http//www.attra.ncat.org.

Mallick M.F.R., Muthukrishnan CR. (1980). Effect of micro nutrients on tomato (Lycopersicon esculentum Mill.), II. Effect on flowering, fruit set and yield. South Indian Horticulture 28 (1), 14-20.

Mehdizadeh M, Darbandi EI, Naseri-Rad H, Tobeh A. (2013). Growth and yield of tomato (Lycopersicon esculentum Mill.) as influenced by different organic fertilizers. International Journal of Agronomy and Plant Production 4(4), 734-738.

Forde BG, Clarkson DT. (1999). Nitrate and ammonium nutrition of plants: Physiological and molecular perspectives. Advances in Botanical Research 30, 1-90.

Imas P, Bar-Yosef B, Kafkafi U, Ganmore-Neumann R. (1997). Release of carboxylic anions and protons by tomato roots in response to ammonium nitrate ratio and $\mathrm{pH}$ in nutrient solution. Plant and Soil 191, 27-34.

Savvas, D., Passam, H. C., Olympios, C., Nasi, E., Moustaka, E., Mantzos, N., \& Barouchas, P. (2006). Effects of ammonium nitrogen on lettuce grown on pumice in a closed hydroponic system. HortScience, 41(7), 1667-1673.

Lea-Cox, J. D., Stutte, G. W., Berry, W. L., \& Wheeler, R. M. (1996). Charge balance--a theoretical basis for modulating $\mathrm{pH}$ fluctuations in plant nutrient delivery systems. Life support \& biosphere science: international journal of earth space, 3(1-2), 53-59.

Gerendás, J., Zhu, Z., Bendixen, R., Ratcliffe, R. G., \& Sattelmacher, B. (1997). Physiological and biochemical processes related to ammonium toxicity in higher plants. Zeitschrift für Pflanzenernährung und Bodenkunde, 160(2), 239-251.

Islam AKMS, Edwards DG, Asher CJ. (1980). pH optima for crop growth. Results of a flowing solution culture experiment with six species. Plant and Soil 54, 339-357. 
Raab TK, Terry N. (1994). Nitrogen-source regulation of growth and photosyn- thesis in Beta vulgaris L. Plant Physiology $105,1159-1166$.

Wright, D.H., and N.D. Harris. (1985). Effect of nitro- gen and potassium fertilization on tomato fla- vor. J Agric. Food Chem. 33:355-358.

Tamilselvi, P., Vijayakumar, R.M. and Nainar, P. (2002). Studies on the effect of foliar application of micronutrients on growth and yield of tomato (Lycopersicon esculentum Mill). Cv. PKM-1. South Ind. Hort., 53 (1-6) : 46-51.

Azmat, R., Hamid, N., Moin, S., \& Saleem, A. (2015). Glomus fasciculatum fungi as a bio-convertor and bio-activator of inorganic and organic $\mathrm{P}$ in dual symbiosis. Recent patents on biotechnology, 9(2), 130-138.

Rakocy, J. E. (1994). Aquaponics: the integration of fish and vegetable culture in recirculating systems (No. 1912-20171480).

Adams, P., \& Ho, L. C. (1995, March). Uptake and distribution ofnutrients in relation to tomato fruit quality. In I International Symposium on Solanacea for Fresh Market 412 (pp. 374-387).

Woldemariam, S. H., Lal, S., Zelelew, D. Z., \& Solomon, M. T. (2018). Effect of potassium levels on productivity and fruit quality of tomato (Lycopersicon esculentum L.). Journal of Agricultural Studies, 6(1), 104-117.

Adams P. (2002). Nutritional control in hydroponics. In: Savvas D, Passam HC (Eds) Hydroponic Production of Vegetables and Ornamentals, Embryo Pub- lications, Athens, Greece, 211-261.

Aghtape, A. A., Ghanbari, A., Sirousmehr, A., Siahsar, B., Asgharipour, M. \& Tavssoli, A. (2011). Effect of irrigation with wastewater and foliar fertilize application on some forage characteristics of foxtail millet (Setaria italica). Int. J. Plant Physiol. Biochem., 3(3), 34-42.

Akl IA, Savvas D, Papadantonakis N, Lydakis-Simantiris N, Kefalas P. (2003). Influence of ammonium to total nitrogen supply ratio on growth, yield and fruit quality of tomato grown in a closed hydroponic system. European Journal of Horticultural Science 68, 204-211.

Anac, D., Eryuce, N., Kilinc, R. (1994). Effect of N, P, K fertilizer levels on yield and quality properties of processing tomatoes in Turkey. Acta Hort., 376, 243-250.

Basavarajeswari, C. P., Hosamni, R. M., Ajjappalavara, P. S., Naik, B. H., Smitha, R. P. \& Ukkund. (2008). Effect of foliar application of micronutrients on growth, yield components of Tomato (Lycopersicon esculentum Mill). Karnataka J. Agri. Sci., 21(3), 428-430. 13

Sultana, S., Islam, M., Khatun, M. A., Hassain, M. A., \& Huque, R. (2017). Effect of foliar application of oligo-chitosan on growth, yield and quality of tomato and eggplant. Asian Journal of Agricultural Research, 11(2), 36-42.

Hassnain, M., Alam, I., Ahmad, A., Basit, I., Ullah, N., Alam, I., ... \& Shair, M. M. (2020). Efficacy of chitosan on performance of tomato (Lycopersicon esculentum L.) plant under water stress condition. Pak J Agric Res, 33(1), $27-41$.

Bidari, B.I., Hebsur, N.S. (2011). Potassium in relation to yield and quality of selected vegetable crops. Karnataka J. Agric. Sci., 24(1), 55-59.

Cheristensen, P. (2005). Foliar fertilization in vine mineral nutrient management prorammes. Vitic Enol., 23, 1-3.

Claussen W. (2002). Growth, water use efficiency, and proline content of hydro- ponically grown tomato plants as affected by nitrogen source and nutrient concentration. Plant and Soil 247, 199-209.

Dasgan HY, Abak K, Cakmak I, Römheld V, Sensoy S. (2004). Inheritance of tolerance to leaf iron deficiency chlorosis in tomato. Euphytica 139, 51-57.

Dasgan HY, Ozturk L, Abak K, Cakmak I. (2003). Activities of iron-contain- ing enzymes in leaves of two tomato genotypes differing in their resistance to Fe chlorosis. Journal of Plant Nutrition 26, 1997-2007. 
Davies, J.N., and G.W. Winsor. (1967). Effect of nitro- gen, phosphorus, potassium, magnesium and liming on the composition of tomato fruit. J. Sci Food Agric. 18:459-466.

Dong C-X, Shen Q-R, Wang G. (2004). Tomato growth and organic acid chan- ges in response to partial replacement of NO3--N by NH4+-N. Pedosphere 14, 159-164.

Errebhi M, Wilcox GE. 1990. Tomato growth and nutrient uptake pattern as influenced by nitrogen form ratio. Journal of Plant Nutrution 13, 1031-1034.

Esna-Ashar M, Zakaie- Khosroshahi M (2008). Physiology and post-harvest technology. Bou Ali Sina Press, 658 pp. F.A.O. (2010).http://www.fao.org/statistics/en/.

Fernández V, Ebert G. 2005. Foliar iron fertilization: A critical review. Journal of Plant Nutrition 28, 2113-2124.

Graber, A., \& Junge, R. (2009). Aquaponic Systems: Nutrient recycling from fish wastewater by vegetable production. Desalination, 246(1-3), 147-156.

Gunes A, Alpaslan M, Inal A. (1998). Critical nutrient concentrations and anta- gonistic and synergistic relationships among the nutrients of NFT-grown young tomato plants. Journal of Plant Nutrition 21, 2035-2047.

Hall, P.O.J., Holby, O., Kollberg, S., Samuelsson, M.O. (1992). Chemical fluxes and mass balancesinamarinefishcagefarm.IV.Nitrogen.MarineEcologyProgressSeries 89, 81-91.

Hartz, T.K., E.M. Miyao, R.J. Mullen, and M.D. Cahn. (2001). Potassium fertilization effects on process- ing tomato yield and fruit quality. Acta Hort 542:127-133.

Hatwar, G. P., Gondane, S. M., Urkade, S. M. \& Gahukar, O. V. (2003). Effect of micronutrients on growth and yield of chilli. Soils and Crops, 13(1), 123-125. 15

El Amerany, F., Meddich, A., Wahbi, S., Porzel, A., Taourirte, M., Rhazi, M., \& Hause, B. (2020). Foliar Application of Chitosan Increases Tomato Growth and Influences Mycorrhization and Expression of Endochitinase-Encoding Genes. International journal of molecular sciences, 21(2), 535.

Benhamou, N.; Thériault, G. (1992). Treatment with chitosan enhances resistance of tomato plants to the crown and root rot pathogen Fusarium oxysporum f. sp. radicis-lycopersici. Physiol. Mol. Plant Pathol. 41, 33-52.

Mohammed, M.A.; Syeda, J.T.M.; Wasan, K.M.; Wasan, E.K. (2017). An overview of chitosan nanoparticles and its application in non-parenteral drug delivery. Pharmaceutics. 9, 53.

Sathiyabama, M.; Akila, G.; Einstein Charles, R. (2014,). Chitosan-induced defence responses in tomato plants against early blight disease caused by Alternaria solani (Ellis and Martin) Sorauer. Arch. Phytopathol. Plant Protect. 47, $1777-1787$.

Gryndler, M.; Jansa, J.; Hršelová, H.; Chvátalová, I.; Vosátka, M. (2003). Chitin stimulates development and sporulation of arbuscular mycorrhizal fungi. Appl. Soil Ecol., 22, 283-287.

Agbodjato, N.A.; Noumavo, P.A.; Adjanohoun, A.; Agbessi, L.; Baba-Moussa, L. (2016). Synergistic effects of plant growth promoting rhizobacteria and chitosan on In vitro seeds germination, greenhouse growth, and nutrient uptake of maize (Zea mays L.). Biotechnol. Res. Int. 11.

Liao, D.; Wang, S.; Cui, M.; Liu, J.; Chen, A.; Xu, G. (2018). Phytohormones regulate the development of arbuscular mycorrhizal symbiosis. Int. J. Mol. Sci.19, 3146

Kaya, C., Kirnak, H., Higgs, D. (2001). Enhancement of growth and normal growth parameters by foliar application of potassium and $\mathrm{P}$ in tomato cultivars grown at high $\mathrm{NaCl}$ salinity. Journal of Plant Nutrition 24, 353-367.

Komosa, A. (1990). Influence of some properties of chemical solutions and nutritional status of plant on efficiency of foliar fertilization of greenhouse tomato. Rocz. AR Poznafi. Research dissertation.

Korshunova YO, Eide D, Clark WG, Guerinot ML, Pakrasi HB. (1999). The IRT1 protein from Arabidopsis thaliana is a metal transporter with a broad substrate range. Plant Molecular Biology 40, 37-44. 
Kowalska, I. (2003). Nutrient and water uptake in different stages of maturity of greenhouse tomato grown on N.F.T. at different sulphate levels in nutrient solution. Acta Sci. Pol., Hortorum Cultus, 2(2), 43-50.

Krom, M.D., Ellner, S., Van Rijn, J., Neori, A., (1995). Nitrogen and phosphorus cycling and transformations in a prototype 'non-polluting' integrated mariculture sys- tem, Eilat, Israel. Marine Ecology Progress Series 118, 25-36. 16

Lacatus, V., C. Botez, M. Chelu, R. Mirghis, and V. Voican. (1994). The influence of organic and min- eral fertilizers on tomato quality for processing. Acta Hort 276:329-332.

Lachover, D. (1972). The effect of potassium on a Roma variety of processing tomato with spe- cial reference to potassium uptake, yield and quality. Qual. Plant Mater. Veg 21 (3):165-177.

Ling HQ, Bauer P, Bereczky Z, Keller B, Ganal M. (2002). The tomato F.E.R. gene encoding a bHLH protein controls ironuptake responses in roots. Pro- ceedings of the National Academy of Sciences U.S.A. 99, 13938-13943.

Marschner H. (1995). Mineral Nutrition of Higher Plants (2nd Edn), Academic Press, London, UK, 889.

Mills HA, Jones Jr. J. (1996). Plant Analysis Handbook II, MicroMacro Publi- shing Inc, Athens, GA, U.S.A., 422.

Nelson, R. L., \& Pade, J. S. (2008). Aquaponic food production: growing fish and vegetables for food and profit.

Oded, A., Uzi, K. (2003). Enhanced performance of processing tomatoes by potassium nitrate based nutrition. Acta Hort., $613,81-87$.

Perkins-Veazie, P. (2003). A rapid spectrophotometric method for analyzing lycopenc content in tomato and tomato products. Postharv. Biol. Technol., 28, 425-430.

Rakocy, J.E., Bailey, D.S., Shultz, K.A., Cole, W.M., (1997). Evaluation of a commercial- scale aquaponic unit for the production of tilapia and lettuce. In: Fourth International Symposium on Tilapia in Aquaculture, vol. 1. 357-372.

Reuter DJ, Robinson JB. (1986.) Plant Analysis, an Interpretation Manual, Inkata Press, Melbourne, Australia, 218 pp Rick CM (1995) Tomato (Lycopersicon esculentum) (Solanaceae). In: Smartt J, Simmonds NW (Eds) Evolution of Crop Plants, Longman, Essex, UK, pp 452-457.

Rezaie H (2014). The Improving and Production of forage crops. The University of Tehran Press. Iran, 428.

Rivero RM, Sánchez E, Ruiz JM, Romero L. (2003). Influence of temperature on biomass, iron metabolism and some related bioindicators in tomato and watermelon plants. Journal of Plant Physiology 160, 1065-1071.

Ruiz JM, Baghour M, Romero L. (2000). Efficiency of the different genotypes of tomato in relation to foliar content of Fe and the response of some bio- indicators. Journal of Plant Nutrition 23, 1777-1786.

Sainju, U. M., Dris, R. \& Singh, B. (2003). Mineral nutrition of tomato.Food, Agriculture and Environment, 2, 176-183.

Schneider, O., Sereti, V., Eding, E.H., Verreth, J.A.J., (2005). Analysis of nutrient flows in integrated intensive aquaculture systems. Aquacultural Engineering 32, 379-401.

Shenker M, Plessner OE, Tel-Or E. (2004). Manganese nutrition effects on tomato growth, chlorophyll concentration, and superoxide dismutase activity. Journal of Plant Physiology 161, 197-202.

Shornikova NM, Tananina TA, Borisova MS (1971). Use of CaCl2 in tomato preservation. Trudy-Vsesoyuznyi- NauchnoLssledovatel,skii-Institut-Kanservano-i- Ovoschchesushil, no-Promyshlennosti, 14: 35-37.

Siddiqi MY, Malhotra B, Min X, Glass ADM. (2002). Effects of ammonium and inorganic carbon enrichment on growth and yield of a hydroponic to- mato crop. Journal of Plant Nutrition and Soil Science 165, 191-197.

Singh, H. M. \& Tiwari, J. K. (2013). Impact of micronutrient spray on growth, yield and quality of tomato (Lycopersicon esculentum Mill). Hort Flora Research Spectrum, 2(1), 87- 89.

Sonneveld C. (2002). Composition of nutrient solution. In: Savvas D, Passam HC (Eds) Hydroponic Production of Vegetables and Ornamentals, Embryo Publications, Athens, Greece, pp 179-210. 
Swan, Z. M., Hafez, S. A. \& Basyony, A. E. (2001). Effect of phosphorus fertilization and foliar application of chelated zinc and calcium on seed, protein and oil yield and oil properties of cotton. J. Agric. Sci., 136, 191-198.

Vasconcelos, A. C. F., Nascimento, C. W. A. \& Filho, F. C. (2011). Distribution of zinc in maize plants as a function of soil and foliar Zn supply. Inter. Res. J. Agric. Sci. Soil Sci., 1(1), 1-5.

Yuan YX, Zhang J, Wang DW, Ling HQ. (2005). AtbHLH29 of Arabidopsis thaliana is a functional ortholog of tomato F.E.R. involved in controlling iron acquisition in strategy I plants. Cell Research 15, 613-621.

Shornikova NM, Tananina TA, Borisova MS (1971). Use of CaCl2 in tomato preservation. Trudy-VsesoyuznyiNauchnoLssledovatel,skii-Institut-Kanservano-iOvoschchesushil, no-Promyshlennosti, 14: 35-37.

Kimball, B. A., \& Mitchell, S. T. (1981). Effects of CO2 enrichment, ventilation, and nutrient concentration on the flavor and vitamin content of tomato fruit.

Le Bot, J., Kirkby, E. A., \& Van Beusichem, M. L. (1990). Manganese toxicity in tomato plants: effects on cation uptake and distribution. Journal of Plant Nutrition, 13(5), 513-525.

Giskin, M., \& Nerson, H. (1984). Foliar nutrition of muskmelon: I. Application to seedlings-greenhouse experiments. Journal of Plant nutrition, 7(9), 1329-1339.

Jifon, J. L., \& Lester, G. E. (2009). Foliar potassium fertilization improves fruit quality of field-grown muskmelon on calcareous soils in south Texas. Journal of the Science of Food and Agriculture, 89(14), 2452-2460.

Tisdale, S.L., W.L. Nelson and J.D. Beaton. (1985). Soil and fertilizer potassium, p. 249-291. In: Soil fertility and fertilizers. (Eds.): S.I. Tisdale, W.I. Nelson and J.D Beaton. 4th ed. MacMillan publ. Co., New York.

Awar, R., \& Karami, E. (2016). Effect of macro and micro elements foliar spray on the qaulity and quantity of tomato (Solanum lycopersicum). IJAPR, 4(2), 22-28.

Rezaei, H., \& Malakouti, M. J. (2001). Critical levels of iron, zinc and boron for cotton in Varamin rigion. Journal of Agricultural Science and Technology, 3(2), 147-153. 